\title{
Adaptasi Sanctification of Marriage Questionnaire: Versi Indonesia untuk Masyarakat Muslim
}

\author{
Hepi Wahyuningsih, Dyna Rahayu Suci Pertiwi \\ Program Studi Psikologi, Fakultas Psikologi dan Ilmu Sosial Budaya, Universitas Islam Indonesia, \\ Yogyakarta
}

\begin{abstract}
Abstrak. Penelitian ini bertujuan untuk mengadaptasi Sanctification of Marriage Questionnaire untuk muslim di Indonesia. Adaptasi dilakukan melalui tahap: penerjemahan, memberikan bukti validitas konstruk, dan reliabilitas. Bukti validitas konstruk dilakukan dengan analisis faktor eksploratori yang dilanjutkan dengan analisis faktor konfirmatori MGCFA (Multi-Group Confirmatory Factor Analysis). Dalam penelitian ini, peneliti menggunakan koefisien reliabilitas komposit. Subjek untuk mengungkap struktur faktor pensakralan perkawinan merupakan 160 individu yang menikah, sedangkan subjek untuk menguji stabilitas struktur faktor pensakralan perkawinan terdiri dari 102 suami dan 111 istri. Hasil analisis faktor eksploratori menunjukkan konstruk pensakralan perkawinan memiliki tiga faktor/dimensi yaitu: keyakinan, pengalaman kualitas kesakralan dan manifestasi Allah. Stabilitas struktur faktor pensakralan perkawinan kemudian diuji secara empiris dengan MGCFA. Hasil MGCFA menunjukkan ketiga faktor/ dimensi pensakralan perkawinan terbukti stabil. Koefisien reliabilitas komposit dari Sanctification of Marriage Questionnaire berada dalam kategori baik. Penelitian selanjutnya dapat dilakukan untuk memberikan bukti validitas konstruk dengan validitas prediktif dan validitas konkuren dari Sanctification of Marriage Questionnaire. Keterbatasan dalam penelitian ini didiskusikan lebih lanjut.
\end{abstract}

Kata Kunci: adaptasi skala, analisis faktor eksploratori, analisis faktor konfirmatori multi kelompok, muslim, pensakralan perkawinan

\section{Adaptation of Sanctification of Marriage Questionnaire: Indonesian Version for Muslim Communities}

Abstract. This study aims to adapt the Sanctification of Marriage Questionnaire for Muslims in Indonesia. Adaptation of the Sanctification of Marriage Questionnaire is carried out through the stages: translation, providing evidence of construct validity and reliability. Evidence of construct validity was carried out by exploratory factor analysis followed by MGCFA (MultiGroup Confirmatory factor Analysis). In this study, we used a composite reliability. Subjects to reveal the factor structure of sanctification of marriage were 160 married individuals, while the subjects to test the stability of factor structure consisted of 102 husbands and 111 wives. The result of exploratory factor analysis shows that the construct of sanctification of marriage has three factors / dimensions, namely: belief, perceived sacred qualities and manifestation of God. The structure stability of sanctification of marriage was then empirically tested by MGCFA. The results of MGCFA showed that the three factors / dimensions of sanctification of marriage proved stable. The composite reliability coefficient of the Sanctification of Marriage Questionnaire was in a good category. Further research can be carried out to provide evidence of construct validity with predictive validity and concurrent validity of the Sanctification of Marriage Questionnaire. Limitations in this study are discussed further.

Keywords: exploratory factor analysis, multi-group confirmatory factor analysis, muslim, sanctification of marriage, scale adaptation

Korespondensi: Hepi Wahyuningsih. Email: hepi.wahyuningsih@uii.ac.id 
Angka perceraian di Indonesia terus mengalami peningkatan. Hal ini terungkap dari pernyataan Kamaruddin Amin bahwa sejak tahun 2015 , terutama pada pasangan yang beragama Islam terjadi peningkatan angka perceraian. Pada tahun 2015 terdapat 394,246 kasus perceraian, kemudian pada tahun 2016 bertambah menjadi 401,717 kasus, tahun 2017 mengalami peningkatan sebanyak 415,510 kasus, pada tahun 2018 terus mengalami peningkatan menjadi 444,358 kasus, dan pada tahun 2019 mencapai 480,618 kasus. Sementara itu, pada 2020, per Agustus jumlahnya sudah mencapai 306,688 kasus. Lebih lanjut Kamaruddin Amin mengemukakan bahwa Bimas Islam terus berupaya menekan angka perceraian melalui program penguatan ketahanan keluarga (Prihatin, 2020). Permasalahan perceraian mengindikasikan rendahnya kualitas perkawinan (He et al., 2018).

Berkaitan dengan kualitas perkawinan, hasil-hasil penelitian menunjukkan secara umum religiusitas berpengaruh terhadap kualitas perkawinan (Aman et al., 2019; Fard et al., 2013; Perry, 2015, 2016a, 2016b, 2016c; Schramm et al., 2012). Mahoney et al. (2003) berpendapat bahwa upaya untuk memajukan kerangka teoritis untuk menjelaskan hubungan yang sering ditemukan antara religiusitas dan fungsi keluarga, termasuk kualitas perkawinan, harus melampaui aspek-aspek agama yang sangat perifer seperti kehadiran di gereja. Mereka mengusulkan bahwa kerangka teoritis harus didasarkan pada fenomena yang dianggap sakral, yang merupakan 'pusat makna agama dan spiritualitas' (Pargament \& Mahoney, 2005).

Religiusitas dan spiritualitas merupakan domain penting bagi goal striving (pencapaian tujuan) bagi sebagian besar individu (Emmons, 2000). Goal/tujuan berpengaruh terhadap kesejahteraan psikologis karena sebagai sumber penting dari makna. Tujuan merupakan komponen motivasional dari makna, menyediakan pedoman hidup, mengorientasikan individu agar hidupnya bertujuan, berharga dan bermakna (Emmons, 2005). Seperti yang dikemukakan oleh Martos et al. (2011) bahwa setiap hari orang berjuang mengejar/meraih tujuan untuk bermacam-macam alasan yang salah satu di antaranya adalah agama. Menurut Pargament (2002), agama dapat membimbing individu dalam mencari kenyamanan emosional, kebermaknaan, intimacy, pengembangan diri, dan kesehatan fisik.

Ada tiga pendapat yang menjelaskan kehadiran agama dalam usaha individu untuk meraih tujuan, yaitu pendapat Gorsuch (1994), Emmons et al. (1998), dan pendapat Mahoney et al. (1999). Gorsuch (1994) memposisikan kembali konsep orientasi religius yang dikemukakan oleh Allport. Menurut Gorsuch, pendapat Allport mengenai orientasi religius mendapat banyak kritik karena tanpa teori dan ketidakjelasan konsep. Gorsuch kemudian berpendapat bahwa orientasi religius khususnya orientasi religius intrinsik dapat 
dijelaskan dengan menggunakan teori motivasi, sehingga religius intrinsik adalah motivasi untuk mengalami dan hidup dalam keimanan demi keyakinan agama.

Pendapat yang kedua, yaitu pendapat Emmons et al (1998) yang menggunakan istilah spiritual personal striving untuk menjelaskan keberadaan agama dalam tujuan yang ingin dicapai individu. Spiritual personal striving didefinisikan sebagai pengakuan adanya Tuhan/Ultimate and Absolute dan keinginan untuk mengorientasikan hidupnya untuk Tuhan/ Ultimate and Absolute.

Pendapat yang ketiga, lahir dari kritik dan keprihatinan Mahoney et al. (1999) terhadap penelitian-penelitian perkawinan yang meneliti variabel religiusitas dengan tidak mengukur bagaimana individu mengintegrasikan agama dalam kehidupan perkawinannya. Dalam penelitian mereka, mereka mengemukakan istilah sanctification of marriage (pensakralan perkawinan) untuk menggambarkan integrasi agama dalam kehidupan perkawinan. Pensakralan perkawinan didefinisikan sebagai persepsi individu yang menikah bahwa perkawinannya memiliki karakter dan makna spiritual.

Dalam perjalanannya, konstruk sanctification tidak hanya diterapkan pada perkawinan, tetapi juga pada aspek kehidupan yang lain, seperti dalam dunia kerja yang disebut sanctification of work (Ada et al., 2020; Carroll et al, 2014; Vem et al., 2019; Walker et al., 2008), dalam pengasuhan disebut sanctification of parenting (Dumas \& NissleyTsiopinis, 2006; Murray-Swank et al., 2006; Volling et al., 2009), dalam peran gender dalam perkawinan (Baker et al, 2009), dan dalam relasi keluarga (Mahoney et al., 2003). Konstruk sanctification juga telah mengalami perubahan definisi, Pargament dan Mahoney (2005) mendefinisikan kembali sanctification sebagai sebuah proses penerimaan bahwa seluruh kehidupan individu memiliki sifat dan arti ilahi. Menurut Pargament dan Mahoney (2005), sanctification adalah sebuah konstruk psikospiritual. Sanctification sebagai konstruk spiritual karena menjelaskan kesakralan mengenai sesuatu. Sanctification merupakan konstruk psikologis karena fokus pada persepsi individu mengenai kesakralan/kesucian dan karena metode yang digunakan untuk mempelajari kesakralan/kesucian mengenai sesuatu adalah metode ilmu sosial, bukan teologi. Sanctification adalah keadaan ketika seseorang mengaitkan kualitas dengan wilayah kehidupan yang biasanya dikaitkan dengan entitas ilahi, suatu bentuk yang dikenal sebagai "kualitas suci/sakral".

Menurut Mahoney (Davis et al., 2018), sanctification juga ditetapkan ke dalam aspek transendensi (misalnya, suci, surgawi, ajaib), nilai dan tujuan tertinggi (misalnya, diberkati, sakral), dan keabadian (misalnya, abadi). Sedangkan menurut Mullins (2016), dalam konteks sosial sanctification memiliki empat makna, yaitu doa, kebaktian dan khotbah, ritual, dan persekutuan. Perkawinan adalah persatuan 
suci yang merupakan "sesuatu yang lebih", yang berarti lebih dari diri sendiri, lebih dari pasangan, dan lebih dari keluarga (Dollahite et al., 2012). Oleh karena itu, pensakralan perkawinan adalah proyeksi memanifestasikan pada citra Tuhan dalam hubungan perkawinan (Zaloudek, 2014). Hal ini dapat diartikan menghubungkan kualitas perkawinan (persepsi, perilaku, hubungan pribadi maupun kedekatan antara kedua pihak, dan dalam menyelesaikan konflik) dengan kualitas sakral terkait pengalaman spiritual dan berhubungan dengan Tuhan.

Terdapat faktor-faktor umum yang mendasari tiga dinamika moralitas transenden dalam perkawinan: 1) Persepsi pasangan tentang Tuhan sebagai ilahi; 2) Kepercayaan memiliki hubungan dengan Tuhan, dalam bentuk ketaatan dan menerima kasih dan karunia; 3) Menganggap perkawinan berpusat pada Tuhan sedemikian rupa sehingga hubungan tersebut ditandai dengan cara individu berurusan dengan Tuhan (Shichida et al., 2015). Menurut Mahoney et al. (1999), pensucian dalam perkawinan memiliki dua aspek, yaitu: individu melihat perkawinannya memiliki kualitas suci (sacred quality) dan individu dapat mengalami perkawinannya sebagai manifestasi dari Tuhan. Aspek pertama menunjukkan bahwa proses pembentukan penilaian terjadi ketika individu menyifatkan kualitas perkawinannya yang sering digunakan dalam tradisi keagamaan seperti diberkati, suci, surga, religius, spiritual. Bentuk pensakralan perkawinan ini merefleksikan tingkat dimana individu mengkarakteristikkan perkawinannya dalam term spiritual, terlepas dari peran faktor eksternal. Adapun aspek kedua mencerminkan tingkat keyakinan individu bahwa perkawinanya adalah manifestasi dari keyakinan dan pengalaman mereka dengan Tuhan. Sejauh mana individu menerima atau meyakini bahwa Tuhan berperan dalam perkawinannya.

Mahoney et al. (1999) kemudian membuat alat ukur untuk mengungkap pengaruh pensakralan perkawinan. Alat ukur ini telah dipakai oleh beberapa peneliti (Brelsford, 2013; Kusner etal,, 2014; McAllister et al., 2020; Reich \& Kalantar, 2018; Sabey et al., 2014). Sebuah penelitian yang dilakukan oleh Phillips et al. (2017) mencoba melakukan validasi awal sanctification of marriage Questionnaire pada pasangan sesama jenis, tetapi hanya terbatas untuk mengetahui koefisien reliabilitas.

Penelitian-penelitian di atas telah menggunakan sanctification of marriage Questionnaire sebagai alat pengambilan data penelitian tetapi belum ada yang mencoba mengeksplorasi lebih lanjut tentang struktur faktor dari konsep ini, sehingga penting untuk mengidentifikasi struktur faktor konsep/ kontruk pensakralan perkawinan. Selain itu, dalam konteks Indonesia yang mayoritas penduduknya beragama muslim, kuesinoner ini juga perlu diadaptasi sehingga nantinya dapat digunakan baik dalam penelitian maupun dalam 
konseling perkawinan dengan responden muslim. Dengan demikian, penelitian ini bertujuan untuk melakukan adaptasi sanctification of marriage Questionnaire untuk responden muslim dan sekaligus mengungkap struktur faktor.

\section{Metode}

\section{Responden penelitian}

Penelitian ini bertujuan untuk mengungkap struktur faktor konstruk pensakralan perkawinan dan kemudian mengkonfirmasi struktur faktor yang ditemukan, sehingga secara metodologi memerlukan dua kelompok responden yang berbeda. Kelompok responden pertama terdiri dari 160 orang yang menikah. Kelompok responden penelitian untuk menguji stabilitas struktur faktor pensakralan perkawinan pada awalnya terdiri dari terdiri 256 orang yang menikah, setelah dilakukan uji normalitas multivarian menjadi 205 orang yang menikah yang terdiri dari dari 102 kelompok suami dan 103 kelompok istri. Pada kelompok suami, usia rata-rata $=43.3$ tahun; rata-rata lama menikah = 15.53 tahun; memiliki dua anak; sebagian besar merupakan pegawai (45\%), wiraswasta $38 \%$, lain-lain 17\%; sebagian besar berpendidikan SMA (51\%), 36\% berpendidikan sarjana, 6\% SMP, dan 7\% berpendidikan SD. Untuk kelompok istri, usia rata-rata $=38.65$ tahun; rata-rata lama menikah = 16.15 tahun; memiliki 2 anak; sebagian besar merupakan ibu rumah tangga (58\%), wiraswasta $24 \%$, pegawai
18\%; sebagian besar berpendidikan SMA (48\%), 31\% berpendidikan sarjana, 18\% SMP, dan 3\% berpendidikan SD.

\section{Pengukuran}

Sanctification of marriage questionnaire merupakan alat ukur yang dikembangkan oleh Mahoney et al. (1999), dengan dua dimensi/ aspek yaitu perceived sacred qualities dan manifestation of God. Alat ukur ini kemudian diadaptasi untuk disesuaikan dengan responden penelitian muslim oleh peneliti. Adaptasi yang dilakukan dengan mengganti kata Tuhan dengan Allah, mengganti kata gereja dengan $\mathrm{Al}$ Qur'an, dan mengganti pilihan jawaban pada dimensi perceived sacred qualities untuk diseragamkan dengan respon jawaban pada dimensi manifestation of God . Skala ini terdiri dari 24 butir, yang terdiri dari 14 butir untuk mengukur manifestasion of god (butir nomor 11 - 24) dan 10 butir untuk mengukur sacred qualities (butir nomor 1 - 10). Dalam skala, responden diminta untuk merespon pernyataan "kata-kata dibawah ini berkaitan dengan gambaran sebuah perkawinan, isilah sesuai dengan kehidupan perkawinan Anda". Alternatif respon yang diberikan, yaitu Sangat Tidak Setuju (STS), Tidak Setuju (TS), Agak Tidak Setuju (ATS), Netral (N), Agak Setuju (AS), Setuju (S), Sangat Setuju (S). Skor bergerak dari 1 (Sangat Tidak Setuju) - 7 (Sangat Setuju).

\section{Metode analisis data}

Construct validity diuji dalam dua langkah, pertama menggunakan exploratory 
factor analysis (EFA) dengan bantuan SPSS versi-26 dan langkah kedua menggunakan confirmatory factor analysis (CFA) dengan bantuan AMOS versi-26. EFA sangat berguna untuk menentukan struktur faktor, sedangkan CFA dilakukan untuk mengkonfirmasi struktur faktor yang ditemukan di EFA dan untuk memberikan bukti lebih lanjut tentang validitas konstruk (Fabrigar \& Wegener, 2012). Exploratory factor analysis menggunakan Principal Axis Factoring (PAF) dan rotasi varimax. PAF digunakan karena tujuan penelitian ini ingin mengetahui struktur faktor yang mendasari sebuah konstruk dari sebuah alat ukur, seperti yang disarankan oleh Fabrigar et al., (1999). Selain itu, PAF juga digunakan untuk data dengan sebagian besar butir tidak terdistribusi normal (Costello \& Osborne, 2005). Rotasi varimax dipilih karena merupakan metode rotasi yang paling umum digunakan (Costello \& Osborne, 2005). Keputusan mengenai jumlah faktor yang dipertahankan ditentukan oleh kriteria KaiserGuttman (Eigenvalue $>1$ ) dan informasi dari literatur sebelumnya tentang jumlah faktor.

Berdasarkan temuan EFA dan teori pensakralan perkawinan, Analisis Faktor Konfirmatori (CFA) dilakukan menggunakan IBM SPSS AMOS versi-26. CFA digunakan untuk memvalidasi hubungan antara faktor dan antara setiap butir dan faktornya (Bowen \& Guo, 2011). Analisis faktor konfirmatori dalam penelitian ini menggunakan multi-group confirmatory factor analysis karena pengukuran dikenakan pada dua kelompok responden, yaitu kelompok istri dan kelompok suami. Byrne (2013) mengemukakan bahwa sebagian besar literatur-literatur SEM ketika membahas analisis faktor konfirmatori multi kelompok menggunakan analisis struktur kovarians (COVS). Jika peneliti bertujuan untuk membangun validitas konstruk sebuah alat ukur, maka peneliti cukup menggunakan COVS. Dalam menguji kesetaraan, ada dua kriteria yang dapat dipakai, yaitu menggunakan $\Delta$ kai kuadrat dan CFI (Byrne, 2013). Menurut Cheung and Rensvold (Byrne, 2013), untuk menguji kesetaraan akan lebih realistis apabila mengacu pada nilai CFI daripada kai kuadrat. Kesetaraan teridentifikasi bila nilai CFI <.01. Delta CFI (CFI) adalah selisih antara model baseline (unconstrained model) dengan model kesetaraan.

Koefisien reliabilitas yang digunakan dalam penelitian ini adalah reliabilitas komposit (Raykov \& Shrout, 2002). Reliabilitas komposit juga mengasumsikan unidimensionalitas seperti halnya reliabilitas Alpha Cronbach. Berbeda dengan koefisien Alpha Cronbach yang mengasumsikan: (a) bahwa besarnya muatan faktor (factor loading) untuk semua aitem sama; dan (b) tidak memperhitungkan kesalahan pengukuran, reliabilitas komposit memperhitungkan kedua hal tersebut (Webster, 2018). Oleh karena penelitian ini melakukan analisis faktor eksploratori dan konfirmatori, maka akan lebih tepat jika menggunakan reliabilitas komposit yang akan dihitung menggunakan bantual excel dengan data yang 
diperoleh dari analisis CFA dengan program AMOS.

\section{Hasil}

Penelitian ini bertujuan untuk melakukan adaptasi sanctification of marriage questionnaire untuk subjek muslim dan sekaligus mengungkap struktur faktor. Hasil analisis peneliti adalah sebagai berikut:

\section{Analisis faktor eksploratori}

Hasil analisis yang menunjukkan nilai signifikansi Bartlett's test of sphericity $\div 2$ (136) $=1503.13, p<.001$ dan nilai Kaiser-Meyer-Olkin Measure of Sampling Adequacy sebesar .828 (> .60) menunjukkan butir-butir dari sanctification of marriage questionnaire kuat untuk dilakukan analisis faktor (Tabachnick \& Fidell, 2012). Hasil analisis faktor eksploratori pada penelitian ini menghasilkan tiga faktor pensakralan perkawinan dengan 17 butir, yaitu keyakinan: (delapan butir dengan eigenvalues sebesar 6.486), pengalaman kualitas kesakralan (enam butir dengan eigenvalues sebesar 2.222) dan manifestasi Allah (tiga butir dengan eigenvalues sebesar 1.696).

Adapun hasil analisis faktor eksploratori dari sanctification of marriage questionnaire secara lebih rinci dapat dilihat pada Tabel 1. Tabel 1 memperlihatkan bahwa analisis faktor eksploratori yang dilakukan terhadap sanctification of marriage questionnaire menghasilkan tiga dimensi/faktor dengan total variance explained sebesar 53.820\%. Dimensi keyakinan mampu menjelaskan konstruk pensakralan perkawinan sebesar $23.92 \%$, dimensi pengalaman kualitas kesakralan mampu menjelaskan konstruk pensakralan perkawinan sebesar $16.68 \%$ dan dimensi manifestasi Allah menjelaskan konstruk pensakralan perkawinan sebesar $13.22 \%$. 


\section{Tabel 1}

Hasil Analisis Faktor Eksploratori Sanctification of Marriage Questionnaire

\begin{tabular}{|c|c|c|c|c|c|c|}
\hline \multirow{2}{*}{$\begin{array}{c}\text { Butir Sanctification of Marriage } \\
\text { Questionnaire }\end{array}$} & \multicolumn{3}{|c|}{ Faktor } & \multirow{2}{*}{$\begin{array}{l}\text { Butir -total } \\
\text { correlation }\end{array}$} & \multirow[t]{2}{*}{$M$} & \multirow[t]{2}{*}{$S D$} \\
\hline & 1 & 2 & 3 & & & \\
\hline \multicolumn{7}{|l|}{ Faktor 1: Keyakinan } \\
\hline $\begin{array}{l}\text { 24. Perkawinan saya mengikuti } \\
\text { apa yang diajarkan agama saya }\end{array}$ & .776 & & & .648 & 6.56 & .632 \\
\hline $\begin{array}{l}\text { 23. Perkawinan saya sesuai dan } \\
\text { mengikuti yang diajarkan dalam } \mathrm{Al} \\
\text { Qur'an }\end{array}$ & .750 & & & .625 & 6.46 & .784 \\
\hline $\begin{array}{l}\text { 19. Perkawinan saya } \\
\text { mencerminkan apa yang } \\
\text { diinginkan Allah Subhanahu Wa } \\
\text { Ta'alla pada saya }\end{array}$ & .731 & & & .490 & 6.31 & .735 \\
\hline $\begin{array}{l}\text { 22. Perkawinan saya } \\
\text { mencerminkan kehadiran Allah } \\
\text { Subhanahu Wa Ta'alla dalam } \\
\text { kehidupan saya }\end{array}$ & .718 & & & .716 & 6.48 & .727 \\
\hline $\begin{array}{l}\text { 21. Perkawinan saya merupakan } \\
\text { ikatan suci }\end{array}$ & .654 & & & .648 & 6.68 & .554 \\
\hline $\begin{array}{l}\text { 20. Perkawinan saya dipengaruhi } \\
\text { oleh tindakan Allah Subhanahu Wa } \\
\text { Ta'alla dalam hidup saya }\end{array}$ & .638 & & & .488 & 6.18 & .955 \\
\hline $\begin{array}{l}\text { 15. Perkawinan saya adalah bukti } \\
\text { dari kepercayaan saya terhadap } \\
\text { Allah }\end{array}$ & .596 & & & .563 & 6.54 & .582 \\
\hline $\begin{array}{l}\text { 17. Perkawinan saya sesuai } \\
\text { dengan identitas perkawinan saya } \\
\text { Faktor } 2 \text { : Kualitas }\end{array}$ & .559 & & & .510 & 6.35 & .665 \\
\hline 5. Luar biasa & & .736 & & .521 & 5.96 & 1.027 \\
\hline 6. Ketuhanan & & .663 & & .580 & 6.56 & .698 \\
\hline 10. Menakjubkan & & .639 & & .454 & 5.56 & 1.400 \\
\hline 7. Rohani & & .614 & & .574 & 6.54 & .760 \\
\hline 8. Religius & & .566 & & .511 & 6.13 & 1.198 \\
\hline 4. Abadi & & .508 & & .324 & 6.36 & 1.055 \\
\hline Faktor 3: Manifestasi Allah & & & & & & \\
\hline $\begin{array}{l}\text { 11. Allah Subhanahu Wa Ta'alla } \\
\text { berperan dalam perkawinan saya }\end{array}$ & & & .889 & .513 & 6.66 & .653 \\
\hline $\begin{array}{l}\text { 12. Allah Subhanahu Wa Ta'alla } \\
\text { turut hadir dalam kehidupan } \\
\text { perkawinan saya }\end{array}$ & & & .794 & .556 & 6.59 & .713 \\
\hline $\begin{array}{l}\text { 13. Perkawinan saya adalah } \\
\text { refleksi dari kehendak Allah } \\
\text { Subhanahu wa Ta'alla }\end{array}$ & & & .544 & .360 & 6.51 & .801 \\
\hline Eigenvalue & 6.486 & 2.222 & 1.696 & & & \\
\hline$\%$ of variance & 23.920 & 16.679 & 13.221 & & & \\
\hline$n$ & 8 & 6 & 3 & & & \\
\hline
\end{tabular}

Catatan. Nilai muatan faktor diatas .05 ditebalkan.

\section{Analisis faktor konfirmatori}

Statistik untuk model pengukuran tiga faktor Sanctification of Marriage
Questionnaire dengan first-order CFA model memiliki tingkat kecocokan model yang baik: Comparative Fit Index (CFI) = .930 (> .90), dan 
Root-Mean-Square Error of Approximation

$($ RMSEA $)=.058(<.08)$. Hasil analisis faktor

konfirmatori multi kelompok dari

Sanctification of Marriage Questionnaire menunjukkan nilai $\Delta$ CFI untuk structural covariances model sebesar .002 (<.01). Adapun hasil analisis faktor konfirmatori multi kelompok pada Sanctification of Marriage Questionnaire dapat dilihat pada Gambar 1 dan Gambar 2.

\section{Gambar 1}

Hasil Analisis Faktor Konfirmatori Multi Kelompok Sanctification of Marriage

Questionnaire pada Kelompok Suami

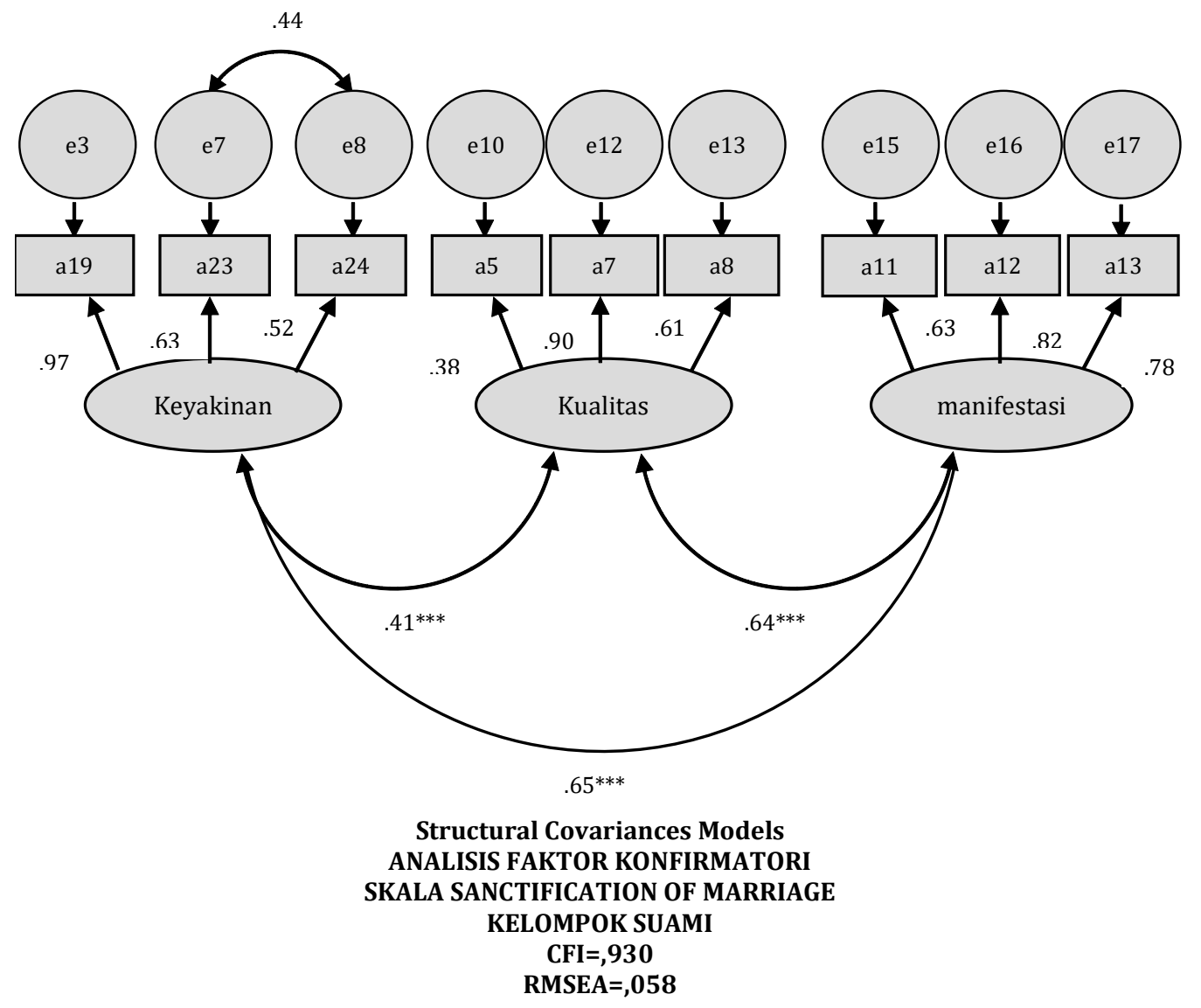




\section{Gambar 2}

Hasil Analisis Faktor Konfirmatori Multi Kelompok Sanctification of Marriage Questionnaire pada Kelompok Istri

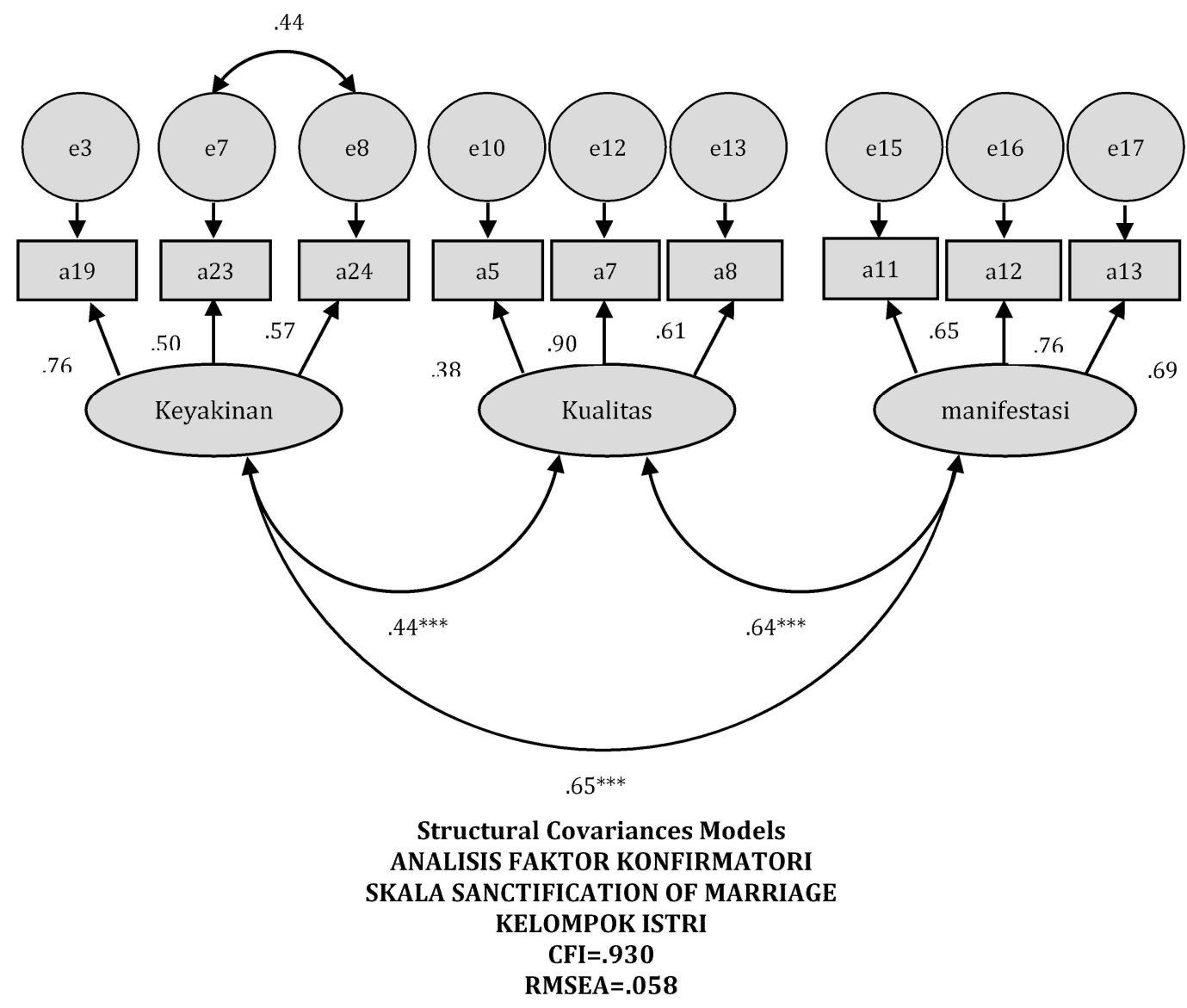

\section{Reliabilitas}

Koefisien reliabilitas komposit sanctification of marriage questionnaire untuk kelompok suami sebesar .95 dengan .93 untuk dimensi keyakinan, .73 untuk dimensi pengalaman kualitas kesakralan, dan 94 untuk dimensi manifestasi Allah. Untuk kelompok istri, nilai koefisien Alpha Cronbach skala sebesar .94 dengan .85 untuk dimensi keyakinan, .71 untuk dimensi pengalaman kualitas kesakralan, dan .91 untuk dimensi manifestasi Allah.

\section{Pembahasan}

Hasil analisis faktor eksploratori menunjukkan konstruk pensakralan perkawinan memiliki tiga dimensi/faktor yaitu: keyakinan, pengalaman kualitas kesakralan dan manifestasi Allah. Hasil ini berbeda dengan teori awal yang menyebutkan bahwa pensakralan perkawinan terdiri dari dua dimensi. Apabila dilakukan telaah lebih lanjut terlihat bahwa dimensi perceived sacred qualities tetap ada, sedangkan dimensi yang awalnya adalah dimensi manifestation of God, terbagi menajdi 
dua dimensi yang kemudian diberi nama baru dimensi keyakinan dan manifestasi Allah. Dalam analisis faktor eksploratori, hal yang demikian dapat diterima karena tujuan awal penelitian ini memang ingin menentukan struktur faktor dari konstruk pensakralan perkawinan sehingga peneliti menggunakan metode Principle Axis Factoring.

Berdasarkan Tabel 1 dapat dilihat bahwa hasil analisis faktor eksploratori telah menghasilkan struktur faktor yang bersih, semua nilai muatan faktor butir di atas .30 tidak ada butir yang cross loading, dan dalam tiap faktor minimal ada tiga butir (Costello \& Osborne, 2005). Tujuh butir yang gugur dalam analisis faktor eksploratori merupakan butir yang nilai faktor loadingnya lebih kecil .50 atau butir yang problematik karena cross loading. Berkaitan dengan nliai muatan faktor, peneliti mengacu pada pendapat Costello dan Osborne (2005) yang mengemukakan nilai muatan faktor dianggap tinggi bila nilainya .50. Nilai muatan faktor yang diperoleh dalam analisis ini banyak yang tinggi sehingga peneliti menetapkan standar minimal muatan faktor sebesar .50 meskipun ada pendapat lain yang mengemukakan bahwa nilai muatan faktor 40 sudah dianggap tinggi (Leech et al, 2015). Nilai total variance explained yang lebih besar 50\% (total variance explained dalam penelitian ini sebesat 53.820\%) menunjukkan hasil EFA dalam penelitian ini memadai. Hal ini mengacu pada pendapat Hair (Netemeyer et al., 2012) bahwa untuk ilmu sosial, hasil EFA dianggap memadai jika total nilai varian yang dijelaskan paling sedikit $50 \%$.

Stabilitas struktur pensakralan perkawinan yang ditemukan dalam analisis faktor eksploratori ini kemudian diuji secara empiris dengan analisis faktor konfirmatori multi kelompok. Hasil analisis faktor konfirmatori multi kelompok menunjukkan ketiga faktor/dimensi pensakralan perkawinan yang ditemukan dalam analisis faktor eksploratori stabil. Hasil analisis faktor konfirmatori multi kelompok menunjukkan bahwa pensakralan perkawinan secara empiris terbukti dapat dijelaskan oleh tiga dimensi, yaitu: keyakinan (tiga butir), pengalaman kualitas kesakralan (tiga butir) dan manifestasi Allah (tiga butir).

Setelah dilakukan analisis faktor konfirmatori, dari 17 butir hasil dari analisis faktor eksploratori menjadi sembilan butir. Butir yang gugur merupakan butir yang nilai faktor loadingnya rendah atau yang berkorelasi negatif dengan butir dalam faktor yang sama. Baik pada kelompok suami maupun istri faktor loading semua butir berada dalam rentang .38 - .97. Hasil analisis analisis faktor konfirmatori multi kelompok juga menunjukkan ketiga dimensi tersebut berkorelasi secara signifikan satu sama lain baik pada kelompok suami maupun pada kelompok istri. Nilai estimasi korelasi antar dimensi yang sangat signifikan tetapi tidak lebih dari .85 menunjukkan sanctification of marriage questionnaire memiliki validitas 
diskriminan yang baik. Dengan demikian dapat disimpulkan bahwa hasil analisis faktor konfirmatori multi kelompok menunjukkan skala ini memiliki validitas konstruk yang baik. Koefisien reliabilitas skala baik pada kelompok suami maupun istri secara keseluruhan juga berada dalam kategori sangat baik. Sehingga alat ukur ini dapat digunakan baik untuk asesmen individu maupun digunakan dalam penelitian.

Berbagai riset sebelumnya mengenai pensakralan perkawinan menunjukkan banyak memiliki keterkaitan dengan beberapa variabel, seperti keyakinan dan budaya (Dollahite et al, 2012), proses transformatif atau transisi perkawinan dan koping dalam perkawinan (Goodman et al., 2013), pengorbanan dalam perkawinan (Stafford et al., 2013), perceraian dalam perkawinan (John, 2017), kepuasan perkawinan (Hwang et al, 2019), dan komitmen perkawinan (Arvia \& Setiawan, 2020). Holland et al (2016) dalam penelitiannya yang bertujuan untuk menguji hubungan antara keintiman spiritual, keintiman perkawinan, dan kesejahteraan menunjukan bahwa terdapat hubungan positif antara keintiman spiritual dengan keintiman perkawinan dan kesejahteraan.

Ketiga aspek yang diungkap dalam skala juga mendukung penelitian sebelumnya. Perry (2015) mengungkapkan aspek kesakralan memiliki peran penting. Ketika perkawinan dianggap sebagai institusi sakral maka akan mempengaruhi empat domain relasional dari spiritualitas relasional dengan: (1) Menciptakan persepsi secara religius yang berorientasi pada tujuan dalam pemilihan pasangan; (2) Mendorong rasa sakral pada hubungan; (3) Meningkatkan kesediaan untuk berkorban dalam perkawinan; dan (4) Membangkitkan pola relasi religius dan spiritual dalam konteks perkawinan. Urgensi aspek keyakinan dalam pensakralan perkawinan diantaranya dijelaskan oleh Rauer dan Volling (2015) dalam penelitiannya mengenai pengaruh keyakinan dan praktik spiritualitas pasangan suami-istri pada pemecahan masalah. Hasil menunjukan bahwa perilaku berorientasi pada pensakralan perkawinan dan aktivitas keagamaan menunjukan pemecahan masalah yang positif.

Seperti halnya penelitian yang lain, penelitian ini juga memiliki kelemahan. Pertama, dalam mengadaptasi alat ukur, peneliti belum melakukan proses adaptasi skala dengan prosedur yang baik, misalnya dengan melalui proses adaptasi yang dikemukakan oleh Beaton et al. (2000). Butir Aitem yang faktor loadingnya rendah ataupun yang cross loading dapat dikarenakan hal tersebut. Selain itu, pilihan jawaban yang disamakan juga dapat mempengaruhi hasil analisis faktor yang dilakukan oleh peneliti.

\section{Simpulan}

Penelitian ini bertujuan untuk melakukan adaptasi sanctification of marriage questionnaire untuk responden muslim dan sekaligus mengungkap struktur faktor. Hasil analisis faktor eksploratori menunjukkan 
konstruk pensakralan perkawinan memiliki tiga dimensi/faktor yaitu: keyakinan, pengalaman kualitas kesakralan dan manifestasi Allah. Stabilitas struktur pensakralan perkawinan yang ditemukan dalam analisis faktor eksploratori ini kemudian diuji secara empiris dengan analisis faktor konfirmatori multi kelompok. Hasil analisis faktor konfirmatori multi kelompok menunjukkan ketiga faktor/dimensi pensakralan perkawinan yang yang ditemukan dalam analisis faktor eksploratori stabil. Koefisien reliabilitas skala baik pada kelompok suami maupun istri secara keseluruhan juga berada dalam kategori baik.

\section{Saran}

Peneliti selanjutnya sebaiknya berhatihati dalam melakukan proses adaptasi dengan mengikuti tahap adaptasi alat ukur yang lebih baik lagi karena dapat mempengaruhi hasil analisis faktor eksploratori dan hasil analisis faktor konfirmatori. Penelitian lebih lanjut diperlukan untuk memperkuat validitas konstruk dari pensakralan perkawinan. Misalnya dapat dilakukan penelitian untuk memberikan bukti validitas dengan RASCH model. Selain itu juga dapat dilakukan penelitian yang lain untuk memberikan bukti validitas prediktif atau validitas konkuren.

\section{Ucapan terimakasih}

Penelitian ini terselenggara berkat dukungan pendanaan dari hibah penelitian Prodi Psikologi Universitas Islam Indonesia tahun 2015.

\section{Referensi}

Ada, H. M., Dehom, S., D’Errico, E., Boyd, K., \& Taylor, E. J. (2020). Sanctification of work and hospital nurse employment outcomes: An observational study. Journal of Nursing Management, September, 1-9. https://doi.org/ 10.1111/jonm.13162

Aman, J., Abbas, J., Nurunnabi, M., \& Bano, S. (2019). The relationship of religiosity and marital satisfaction: The role of religious commitment and practices on marital satisfaction among Pakistani respondents. Behavioral Sciences, 9(3), 1-13. https://doi.org/10.3390/ bs 9030030

Arvia, A., \& Setiawan, J. L. (2020). Kepuasan pernikahan pesangan beda etnis ditentukan resolusi konflik dan intimasi spiritual. Jurnal Psikologi Teori Dan Terapan, 11(1), 17-31. https://doi.org/ 10.26740/jptt.v11n1.p17-31

Baker, E. H., Sanchez, L. A., Nock, S. L., \& Wright, J. D. (2009). Covenant marriage and the sanctification of gendered marital roles. Journal of Family Issues, 30(2), 147-178. h ttp s : / / do i.org / 10.1177 / 0192513X08324109

Beaton, D. E., Bombardier, C., Guillemin, F., \& Ferraz, M. B. (2000). Guidelines for the process of cross-cultural adaptation of self-report measures. Spine, 25(24), 3186-3191. https://doi.org/10.1097/ 00007632-200012150-00014

Bowen, N. K., \& Guo, S. (2011). Structural equation modeling. Oxford University Press. https://doi.org/10.1093/ acprof:oso/9780195367621.001.0001

Brelsford, G. M. (2013). Sanctification and spiritual disclosure in parent-child relationships: Implications for family relationship quality. Journal of Family Psychology, 27(4), 639-649. https:// doi.org/10.1037/a0033424

Byrne, B. M. (2013). Structural equation modeling with AMOS. In Structural 
Equation Modeling With AMOS. https:// doi.org/10.4324/9781410600219

Carroll, S. T., Stewart-Sicking, J. A., \& Thompson, B. (2014). Sanctification of work: assessing the role of spirituality in employment attitudes. Mental Health, Religion and Culture, 17(6), 545-556. h ttps://doi.org / 10.1080 / 13674676.2013.860519

Costello, A., \& Osborne, J. W. (2005). Exploratory Factor Analysis: Four recommendations for getting the most from your analysis. Practical Assessment, Research and Evaluation, 10(7), 1-9. http:// pareonline.net/pdf/v10n7.pdf

Davis, J. M., Horrell, K. E., Anderson, T. L., \& Lewis Hall, M. E. (2018). Religious and role contributions to the marital satisfaction of evangelical women. Journal of Psychology and Theology, 46(3), 184-198. https://doi.org/ 10.1177/0091647118794244

Dollahite, D. C., Hawkins, A. J., \& Parr, M. R. (2012). "Something more": The meanings of marriage for religious couples in America. Marriage \& Family Review, 48(4), 339-362. https://doi.org/ 10.1080/01494929.2012.674480

Dumas, J. E., \& Nissley-Tsiopinis, J. (2006). RESEARCH: Parental global religiousness, sanctification of parenting, and positive and negative religious coping as predictors of parental and child functioning. International Journal for the Psychology of Religion, 16(4), 289-310. https://doi.org/ 10.1207/s15327582ijpr1604_4

Emmons, R. A. (2000). Is spirituality an intelligence? Motivation, cognition, and the psychology of ultimate concern. International Journal for the Psychology of Religion, 10(1), 3-26. https://doi.org/10.1207/ S15327582IJPR1001_2

Emmons, R. A. (2005). Striving for the sacred: Personal goals, life meaning, and religion. Journal of Social Issues, 61(4), 731-745. https: //doi.org/10.1111/j.15404560.2005.00429.x

Emmons, R. A., Cheung, C., \& Tehrani, K. (1998). Assessing spirituality through personal goals: Implications for research on religion and subjective well-being. Social Indicators Research, 45(1), 391-422. h ttp s: / / doi.org/10.1023/ A:1006926720976

Fabrigar, L. R., \& Wegener, D. T. (2012). Exploratory faktor analysis/ : Understanding Statistic. Oxford University Press.

Fabrigar, L. R., Wegener, D. T., MacCallum, R. C., \& Strahan, E. J. (1999). Evaluating the use of exploratory factor analysis in psychological research. Psychological Methods, 4(3), 272-299. https://doi.org/ 10.1037/1082-989X.4.3.272

Fard, M. K., Shahabi, R., \& Zardkhaneh, S. A. (2013). Religiosity and marital satisfaction. Procedia - Social and Behavioral Sciences, 82, 307-311. https:/ /doi.org/10.1016/j.sbspro.2013.06.266

Goodman, M. A., Dollahite, D. C., Marks, L. D., \& Layton, E. (2013). Religious faith and transformational processes in marriage. Family Relations: An Interdisciplinary Journal of Applied Family Studies, 62(5), 808-823. https://doi.org/10.1111/ fare. 12038

Gorsuch, R. L. (1994). Toward motivational theories of intrinsic religious commitment. Journal for the Scientific Study of Religion, 33(4), 315-325.

He, Q., Zhong, M., Tong, W., Lan, J., Li, X., Ju, X., \& Fang, X. (2018). Forgiveness, marital quality, and marital stability in the early years of Chinese marriage: An actorpartner interdependence mediation model. Frontiers in Psychology, 9, 1-11. h ttps://doi.org / 10.3389 / fpsyg.2018.01520

Holland, K. J., Lee, J. W., Marshak, H. H., \& Martin, L. R. (2016). Spiritual intimacy, marital intimacy, and physical/psychological 
well-being: Spiritual meaning as a mediator. Psychology of Religion and Spirituality, 8(3), 218-227. https:// doi.org/10.1037/rel0000062

Hwang, W., Yoon, J., Silverstein, M., \& Brown, M. T. (2019). Husband-wife religious discordance, marital satisfaction, and risk of marital dissolution in two generations. Journal of Family Issues, 40(9), 1201-1223. https://doi.org/ 10.1177/0192513X19835871

Kusner, K. G., Mahoney, A., Pargament, K. I., \& De Maris, A. (2014). Sanctification of marriage and spiritual intimacy predicting observed marital interactions across the transition to parenthood. Journal of Family Psychology, 28(5), 604614. https://doi.org/10.1037/a0036989

Leech, N. L., Barret, K. C., \& Morgan, G. A. (2015). IBM SPSS for intermediate statistics (5th ed.). Routledge Taylor \& Francis Group.

Mahoney, A., Pargament, K. I., Jewell, T., Swank, A. B., Scott, E., Emery, E., \& Rye, M. (1999). Marriage and the spiritual realm: The role of proximal and distal religious constructs in marital functioning. Journal of Family Psychology, 13(3), 321-338. https: / / doi.org/10.1037/08933200.13.3.321

Mahoney, A., Pargament, K. I., Murray-swank, A., \& Murray-swank, N. (2003). Religion and the sanctification of family relationships. Review of Religious Research, 44(3), 220-236. https:// doi.org/10.2307/3512384

Martos, T., Kézdy, A., \& Horváth-Szabó, K. (2011). Religious motivations for everyday goals: Their religious context and potential consequences. Motivation and Emotion, 35(1), 75-88. https:// doi.org/10.1007/s11031-010-9198-1

McAllister, P., Henderson, E., Maddock, M., Dowdle, K., Fincham, F. D., \& Braithwaite, S. R. (2020). Sanctification and cheating among emerging adults. Archives of Sexual Behavior, 49(4), 1177-1188. https:// doi.org/10.1007/s10508-020-01657-3
Mullins, D. (2016). The effects of religion on enduring marriages. Social Sciences, 5(24), 1-15. https://doi.org/10.3390/ socsci5020024

Murray-Swank, A., Mahoney, A., \& Pargament, K. I. (2006). Research: Sanctification of parenting: Links to corporal punishment and parental warmth among biblically conservative and liberal mothers. International Journal of Phytoremediation, 21(1), 271-287. h ttps://doi.org/10.1207/ s15327582ijpr1604_3

Netemeyer, R., Bearden, W., \& Sharma, S. (2012). Scaling procedures. Scaling Procedures. h t tp s: / / doi.org / 10.4135/ 9781412985772

Pargament, K. I. (2002). Is religion nothing but ...? Explaining religion versus explaining religion away. Psychological Inquiry, 13(3), 239-244. https://doi.org/ 10.1207/S15327965PLI1303_06

Pargament, K. I., \& Mahoney, A. (2005). Sacred matters: Sanctification as a vital topic for the psychology of religion. International Journal for the Psychology of Religion, 15(3), 179-198. https://doi.org/ 10.1207/s15327582ijpr1503_1

Perry, S. L. (2015). A match made in heaven? Religion-based marriage decisions, marital quality, and the moderating effects of spouse's religious commitment. Social Indicators Research, 123(1), 203-225. https://doi.org/ 10.1007/s11205-014-0730-7

Perry, S. L. (2016a). From bad to worse? Pornography consumption, spousal religiosity, gender, and marital quality. Sociological Forum, 31(2), 441-464. https://doi.org/10.1111/socf.12252

Perry, S. L. (2016b). Perceived spousal religiosity and marital quality across racial and ethnic groups. Family Relations, 65(2), 327-341. https:// doi.org/10.1111/fare.12192

Perry, S. L. (2016c). Spouse's religious commitment and marital quality: Clarifying the role of gender. Social Science 
Quarterly, 97(2), 476-490. https:// doi.org/10.1111/ssqu.12224

Phillips, R. E., Kalp, D., Lucci, M., Maccarelli, A., Avant, S., Cenkner, D., \& Herndon, R. (2017). Initial validation of measures of sanctification in same-sex romantic relationships and sexual behavior. Journal for the Scientific Study of Religion, 56(4), 836-851. https:// doi.org/10.1111/jssr.12488

Prihatin, I. . (2020). Kemenag Sebut Angka Perceraian Mencapai 306.688 Per Agustus 2020. https://www.merdeka.com/ peristiwa/kemenag-sebut-angkaperceraian-mencapai-306688-peragustus-2020.html

Rauer, A., \& Volling, B. (2015). The role of relational spirituality in happily-married couples' observed problem-solving. Psychology of Religion and Spirituality, 7(3), 239-249. https://doi.org/10.1037/rel0000022

Raykov, T., \& Shrout, P. E. (2002). Reliability of scales with general structure: Point and interval estimation using a structural equation modeling approach. Structural Equation Modeling, 9(2), 195-212. https:/ /doi.org/10.1207/S15328007SEM0902_3

Reich, N., \& Kalantar, S. M. (2018). The role of praying for the spouse and sanctification of marriage in reducing infidelity. Mental Health, Religion and Culture, 21(1), 65-76.https://doi.org/ 10.1080/13674676.2018.1447555

Sabey, A. K., Rauer, A. J., \& Jensen, J. F. (2014). Compassionate love as a mechanism linking sacred qualities of marriage to older couples' marital satisfaction. Journal of Family Psychology, 28(5), 594603. https://doi.org/10.1037/a0036991

Schramm, D. G., Marshall, J. P., Harris, V. W., \& Lee, T. R. (2012). Religiosity, homogamy, and marital adjustment: An examination of newlyweds in first marriages and remarriages. Journal of Family Issues, 33(2), 246-268. https://doi.org/ $10.1177 / 0192513 X 11420370$

Shichida, T., Dollahite, D. C., \& Carroll, J. S. (2015). How the perception of God as a transcendent moral authority influences marital connection among American christians. Journal of Psychology and Christianity, 34(1), 40-52. http:// lib.byu.edu/about/copyright/

Stafford, L., David, P., \& McPherson, S. (2013). Sanctity of marriage and marital quality. Journal of Social and Personal Relationships, 31(1), 54-70. https:// doi.org/10.1177/0265407513486975

Tabachnick, B. G., \& Fidell, L. S. (2012). Using multivariate statistics (6th ed). Prentice Hall

Vem, L. J., Mbasua, Y. A., \& Davireng, M. (2019). Sanctification of work and turnover of teachers under insurgency: Would career satisfaction and affective commitment mediate the relationship? Journal of Educational Administration, 58(2), 171-186. https://doi.org/ 10.1108/JEA-03-2019-0039

Volling, B. L., Mahoney, A., \& Rauer, A. J. (2009). Sanctification of parenting, moral socialization, and young children's conscience development. Psychological of Religion and Spiritual, 1(1), 53-68. https://doi.org/10.1037/a0014958

Walker, A. G., Jones, M. N., Wuensch, K. L., Aziz, S., \& Cope, J. G. (2008). Sanctifying work: Effects on satisfaction, commitment, and intent to leave. International Journal for the Psychology of Religion, 18(2), 132145.https: / / doi.org/10.1080/ 10508610701879480

Webster, G. D. (2018). Measurement in social psychology. In Measurement in Social Psychology. https://doi.org/10.4324/ 9780429452925

Zaloudek, J. (2014). Evangelicals' sanctification of marriage through the metaphor of Jesus as a husband. Religions, 5, 623-647. https://doi.org/10.3390/rel5030623

Received 19 October 2020

Revised 1 January 2021

Accepted 13 January 2021 